Original Research Paper

\title{
Kandungan Logam Berat Pb Undur-Undur Laut dan Implikasinya Pada Kesehatan Manusia
}

\author{
Cyrum Barnike Beru Ketaren', Agus Alim Hakim², Achmad Fahrudin ${ }^{2 *}$, Yusli Wardiatno ${ }^{2,3}$ \\ ${ }^{1}$ Program Magister Pengelolaan Sumberdaya Pesisir dan Lautan, Sekolah Pascasarjana, Institut Pertanian Bogor, \\ Kampus Bogor Darmaga, Bogor 16680 \\ ${ }^{2}$ Departemen Manajemen Sumberdaya Perairan, Fakultas Perikanan dan Ilmu Kelautan, Institut Pertanian Bogor, \\ Kampus IPB Dramaga, Bogor 16680 \\ ${ }^{3}$ Pusat Penelitian Lingkungan Hidup, Institut Pertanian Bogor Kampus IPB Darmaga, Bogor 16680
}

\author{
Article history \\ Received: 24 Februari 2019 \\ Revised: 10 Maret 2019 \\ Accepted: 17 Maret 2019 \\ Published: 28 Maret 2019 \\ *Corresponding Author: \\ Achmad Fahrudin, Dosen \\ Manajemen Sumberdaya \\ Perairan FPIK Institut \\ Pertanian Bogor \\ Indonesia \\ Email: \\ fahrudina@yahoo.com
}

\begin{abstract}
The mole crab (Hippidae) is a filter feeder organism from crustacean that inhabits in sandy coastal areas. Due to its nature, this organism is able to accumulate heavy metals in a large amount. The concentration of heavy metals in this organism will increase in line with the polluting condition of its habitat. Heavy metals which exceed the standard in the organism body will be implicated to the human health who consumes the organism. The sandy crabs are found in large amount in Widara Payung coastline, Cilacap Regency. They are captured by the locals for meals. The heavy metal content such as Lead in the organism body never been investigated in this area previously. This research aimed to estimate the health risk of people who consume the sandy crabs in the area of Widara Payung, Cilacap Regency. This research was conducted on April to May 2018 and a location of sampling was determined purposively. Samples consisted of three types namely sandy crab body, sediment, and seawater. Each sample was preserved in an ice box and then transported to Aquatic Productivity and Environment Laboratory in Bogor Agricultural Univeristy for heavy metal analyzing. Results of this research exhibited that the average of Lead content in the water, sediment, and body of the sandy crab were $0.007 \mathrm{mg} / 1,43.43 \mathrm{mg} / \mathrm{kg}, 0,97 \mathrm{mg} / \mathrm{kg}$, respectively. The Lead content in the crab body the standard issued by the government of Indonesia through the BPOM, namely $0.20 \mathrm{mg} / \mathrm{kg}$. Regular monitoring of $\mathrm{Pb}$ concentration in the mole crab and its habitat is suggested.
\end{abstract}

Keywords: consumption, Emerita emeritus, Hippidae, intertidal, pollution

Abstrak : Undur-undur laut (Hippopidae) adalah crustacea filter feeder yang hidup di daerah pantai intertidal berpasir. Karena sifatnya, organisme ini mampu mengakumulasi logam berat dalam jumlah besar. Konsentrasi logam berat dalam organisme ini akan meningkat sejalan dengan kondisi polusi habitatnya. Logam berat yang melebihi standar dalam tubuh organisme akan berimplikasi pada kesehatan manusia yang mengkonsumsi organisme tersebut. Undur-undur laut dapat ditemukan dalam jumlah besar di pesisir Widara Payung, Kabupaten Cilacap. Mereka ditangkap oleh penduduk setempat untuk dikonsumsi. Kandungan logam berat seperti $\mathrm{Pb}$ dalam tubuh undur-undur laut belum pernah diteliti di daerah ini sebelumnya. Penelitian ini bertujuan untuk menentukan konsentrasi timbal $(\mathrm{Pb})$ pada undur-undur laut dan implikasinya terhadap kesehatan manusia bila mengkonsumsinya di daerah Widara Payung, Kabupaten Cilacap. Penelitian dilakukan pada bulan April sampai Mei 2018 dan lokasi pengambilan sampel ditentukan secara purposif. Sampel terdiri dari tiga jenis yaitu undur-undur laut, sedimen, dan air laut. Setiap sampel yang diambil disimpan dalam kotak pendingin dan kemudian dibawa ke Laboratorium Produktivitas dan Lingkungan Perairan di Institut Pertanian 
Bogor untuk analisis logam berat. Hasil penelitian ini menunjukkan bahwa rata-rata kandungan $\mathrm{Pb}$ dalam air, sedimen, dan undur-undur laut masingmasing adalah 0,007 mg/l, 43,43 mg $/ \mathrm{kg}, 0,97 \mathrm{mg} / \mathrm{kg}$. Kandungan timbal dalam undur-undur laut telah melampaui standar yang telah dikeluarkan oleh pemerintah Indonesia melalui BPOM yaitu $0,20 \mathrm{mg} / \mathrm{kg}$. Dengan nilai tersebut, konsumsi undur-undur laut memiliki resiko kesehatan pada manusia. Monitoring kandungan logam di lingkungan habitat dan pada undur-undur laut menjadi prioritas.

Kata kunci: Emerita emeritus, Hippidae, intertidal, konsumsi, pencemaran

\section{Pendahuluan}

Undur-undur laut (Hippopidae) merupakan golongan krustasea yang hidup di pantai berpasir. Kepiting ini juga dikenal dengan nama mole crab, sand $c r a b$, di beberapa daerah dikenal dengan nama yutuk. Undur-undur laut mempunyai fungsi ekonomi dan ekologi (Mashar et al., 2013). Undur-undur laut memiliki peran ekologi yang cukup penting pada habitat alaminya di perairan intertidal, yaitu berperan dalam siklus atau rantai makanan (sebagai makanan bagi hewan pantai, seperti burung pantai/laut, ikan, dan sea otter). Selain itu, memiliki peran sebagai indikator lingkungan perairan, yaitu bioindikator pencemaran pestisida, tumpahan minyak, merkuri, dan indikasi kandungan asam domoik (neurotoksin yang dihasilkan oleh diatom) (Siegel \& Wenner, 1984; Wenner, 1988; Pérez, 1999; Dugan et al., 2005). Spesies ini juga sebagai spesies indikator dan organisme model pada kajian pengaruh panas buangan pembangkit listrik tenaga atom (Subramoniam, 2014). Undur-undur laut memiliki fungsi ekonomi untuk nelayan. Pemanfaatan undur-undur laut untuk kepentingan ekonomi hanya dilakukan di wilayah pesisir selatan Jawa Tengah, terutama di Kabupaten Cilacap dan Kebumen (Mashar, 2016).

Lebih dari itu, undur-undur laut juga mempunyai nilai ekonomi yang tidak sedikit bagi lima komponen masyarakat yang terdapat di wilayah pesisir Kabupaten Cilacap dan Kebumen, yaitu kelompok penangkap (nelayan), pengumpul, pengolah, pedagang, dan konsumen atau yang mengkonsumsi undur-undur laut (Bhagawati et al., 2016). Potensi ekonomi undurundur laut di Kabupaten Cilacap sebesar Rp. 64.500.000 (Mashar et al., 2016). Undur-undur laut mempunyai nilai kesehatan yang cukup tinggi hal ini dikarenakan mengandung protein, omega-3, dan omega-6 cukup tinggi, sehingga dapat dimanfaatkan sebagai sumber protein (Hartono et al., 2011)
Diantara wilayah-wilayah pantai di Indonesia tersebut, undur-undur laut banyak di jumpai di pantai Kebumen dan Cilacap, Jawa Tengah, dan di kedua lokasi dikenal dengan nama lokal "yutuk" dan merupakan target tangkapan nelayan perikanan pada wilayah intertidal (Mashar., et al. 2013). Daerah penyebaran undur-undur laut di pesisir selatan provinsi Jawa Tengah terutama di Kabupaten Cilacap dan Kebumen (Muzammil et al., 2015).

PLTU dengan bahan bakar batu bara di Pantai Bunton membawa dampak pencemaran yang dihasilkan melalui buangan. Bahan bakar batu bara memilki kandungan logam berat. Peningkatan pemanfaatan batu bara sebagai pembangkit tenaga listrik memberikan dampak yang positif, tetapi juga memberikan dampak yang dapat merugikan lingkungan. Proses pembakaran batu bara di PLTU akan menghasilkan sisa pembakaran berupa limbah padat abu dasar (bottom ash) $25 \%$ dan abu terbang (fly ash) $75 \%$. Abu terbang merupakan partikel abu yang sangat halus yang terbawa oleh gas buang sedangkan abu dasar merupakan abu yang tertinggal dan dikeluarkan dari bawah boiler. Abu batu bara diindikasikan mengandung logam-logam berat toksik seperti $\mathrm{Pb}, \mathrm{Cr}, \mathrm{Cu}, \mathrm{Ni}$, dan $\mathrm{Cd}$. Batu bara mengandung elemen kimia mayor terdiri dari $\mathrm{As}, \mathrm{B}, \mathrm{Cd}, \mathrm{Hg}, \mathrm{Mo}, \mathrm{Pb}$, $\mathrm{Se}, \mathrm{S}$, serta minor yang terdiri dari $\mathrm{Cr}, \mathrm{Cu}, \mathrm{Ni}, \mathrm{V}, \mathrm{Zn}$, F, dan Cl. (Jaffrennou et al., 2007).

Logam berat yang terkandung dalam batu bara dapat menimbulkan polusi dan masuk kebadan perairan. Adanya logam berat di perairan, berbahaya baik secara langsung terhadap kehidupan organisme, maupun efeknya secara tidak langsung terhadap kesehatan manusia. Hal ini berkaitan dengan sifat-sifat logam berat yang sulit didegradasi dan keberadaannya secara alami sulit dihilangkan. Logam berat dapat terakumulasi dalam organisme laut termasuk kerang dan ikan. Slain itu, logam berat juga dapat berada di dalam sedimen. Logam berat yang masuk ke perairan pada kadar di atas batas baku mutu akan mencemari 
perairan laut. Logam berat yang mencemari perairan akan mengendap pada sedimen dan tubuh makhluk hidup melalui proses bioakumulasi.

Kabupaten Cilacap sudah berkembang menjadi daerah industri sejak tahun 1974 dan saat ini telah memiliki lima kawasan industri. Kegiatan industri membawa dampak positif terhadap perekonomian masyarakat namun dilain pihak membawa dampak negatif terhadap lingkungan terutama pada perairan laut. Dampak negatif yang diberikan dari kegiatan tersebut diantarnya buangan limbah industri. Salah satu limbah yang masuk kedalam perairaan ialah limbah timbal $(\mathrm{Pb})$ yang diduga telah terakumulasi dalam tubuh organisme. Organisme yang mampu menjadi indikator logam berat diantara ialah undur-undur laut. Undur-undur laut berperan sabagai bioindikator pencemaran pestisida, tumpahan minyak, dan kandungan asam dumoik (Siegel \& Wenner, 1984; Wenner, 1988).

Timbal $(\mathrm{Pb})$ merupakan logam berat yang berada di kerak bumi, memiliki titik lebur rendah sehingga digunakan untuk melapisi logam agar tidak mudah terjadi perkaratan. Titik lebur yang rendah memudahkan untuk digunakan sehingga biaya operasi lebih rendah. $\mathrm{Pb}$ merupakan sejenis logam lunak berwarna cokelat kehitaman dan mudah dimurnikan dari pertambangan sehingga mudah dibentuk. Selain itu, dapat dicampurkan ke logam murni lainya. Kepadatannya melebihi logam lain. Kelarutan timbal $(\mathrm{Pb})$ dalam air cukup rendah sehingga kadarnya relatif sedikit. Bahan bakar yang mengandung timbal (lead gasoline) memberikan kontribusi yang berarti bagi keberadaan timbal $(\mathrm{Pb})$ di perairan. Keberadaan timbal $(\mathrm{Pb})$ di perairan dapat mengkontaminasi ekosistem perairan, hingga terakumulasi pada biota air dan sedimen. Biota air yang mengandung timbal $(\mathrm{Pb})$ pada konsentrasi tertentu dapat membahayakan biota tersebut dan bersifat toksik jika masuk ke tubuh manusia (Besser et al., 2007). Penelitian ini bertujuan untuk mengestimasi risiko kesehatan masarakat yang mengkonsumsi undur-undur laut.

\section{Bahan dan Metode}

\section{Waktu dan lokasi pengambilan sampel}

Penelitian ini dilakukan di Perairan Cilacap meliputi wilayah Pantai Widara Payung Maret- April 2018. Pengambilan dilakukan di tiga lokasi dengan pengulangan uji sampel di laboratorium sebanyak tiga kali ulangan. Lokasi pengambilan sampel merupakan pantai Widara Payung, Kecamatan Adipala, Kabupaten
Cilacap. Lokasi pengambilan sampel terletak pada koordinat $7^{\circ} 41,943^{\prime}$ LS dan $109^{\circ} 15,848^{\prime}$ BT (Gambar 1). Analisis laboratorium dilakukan di Laboratorium Produktivitas dan Lingkungan Perairan, Institut Pertanian Bogor.

\section{Pengambilan dan Prepasi Sampel}

Pengambilan sampel air dilakukan pada kedalaman $30 \mathrm{~cm}$ dengan estimasi sampel air dari dasar dan permukaan air telah homogen. Pengambilan sampel sedimen dilakukan dengan mengunakan corer berukuran 5 inchi dengan dimasukan kedalam badan perairaan $\pm 15 \mathrm{~cm}$. Sampel di air diambil mengunakan botol, sementara sampel sedimen dimasukan kedalam wadah plastik dan diberi label. Sampel biota undurundur laut diambil dari hasil tangkapan nelayan. Ketiga jenis sampel (air, sedimen, dan biota) dijaga pada suhu rendah dengan mengunakan ice pack untuk dibawa ke laboratorium untuk dilakukan analisis. Sampel yang diawetan dengan mengunakan ice pack waktu membawa sampel hingga ke lokasi pengujian tidak lebih dari 1 X 24 jam.

\section{Analisis Laboratorium}

Ketiga jenis sampel (air, sedimen, dan biota) dilakukan analisis kandungan logam berat timbal $(\mathrm{Pb})$. Metode analisis logam berat timbal menggunakan metode (APHA, 2005), sehingga didapatkan konsentrasi logam berat pada sedimen $(\mathrm{mg} / \mathrm{kg})$, air $(\mathrm{mg} / \mathrm{l})$, dan biota $(\mathrm{mg} / \mathrm{kg})$.

\section{Analisa Data}

\section{Risiko kesehatan pencemaran logam berat timbal $(\mathrm{Pb})$ di pesisir pantai Widara Payung}

Tahapan dalam analisis risiko yaitu identifikasi bahaya, analisis dosis-respon, analisis pemajanan, dan karakterisasi risiko. Langkah-langkah ini tidak harus dilakukan secara berurutan, kecuali karakterisasi risiko sebagai tahap terakhir (IPCS, 2004).

\section{Identifikasi Bahaya}

Tahap pertama dalam analisa risiko adalah identifikasi lokasi dan identifikasi sumber-sumber bahaya yang ada dalam lokasi penelitian. Sumber bahaya yang akan diidentifikasi adalah konsentrasi logam $\mathrm{Pb}$. Identifikasi logam $\mathrm{Pb}$ dilakukan dengan 
mengukur konsentrasinya baik di air, sedimen, dan biota (undur-undur laut) yang terdapat di perairan pantai Widara Payung.

\section{Analisis Dosis-Respon}

Tahap kedua ialah analisis dosis-respon yaitu masing-masing logam berat harus diketahui nilai dosis referensinya. Dosis referensi adalah jumlah zat kimia yang memajani manusia setiap hari dalam waktu lama (umumnya sepanjang hayat) yang tidak menimbulkan efek merugikan. Dosis referensi untuk efek-efek nonkarsinogenik dinyatakan sebagai Reference Dose (RfD) sedangkan efek-efek karsinogenik dinyatakan sebagai Cancer Slope Factor (CSF). Nilai RfD dan CSF berbeda pada masing-masing logam berat, nilai tersebut diperoleh melalui studi pustaka terhadap penelitian yang berkaitan. Nilai RfD dan CSF untuk logam $\mathrm{Pb}$ masing-masing sebesar 0.004 (US EPA, 2000) dan 0.042 (Huboyo \& Syafrudin, 2007).

\section{Analisis Pemajanan}

Tahap selanjutnya dalam analisis risiko kesehatan adalah analisis pemajanan. Tahap ini meliputi prakiraan alur pajanan kontaminan pada media pencemar dan potensi risiko mencemari populasi. Analisis pemajanan pada masyarakat yang mengkonsumsi undur-undur laut dilakukan dengan menghitung laju asupan makanan undur-undur laut dan frekuensi pajanan per harinya. Laju asupan undurundur laut pada masyarakat di sekitar perairan pantai Widara Payung didapatkan dengan menghitung berapa banyak undur-undur laut yang dimakan oleh masyarakat per harinya. Frekuensi pajanan diperoleh dengan mengetahui berapa banyak masyarakat mengkonsumsi undur-undur laut hari tiap tahunnya.

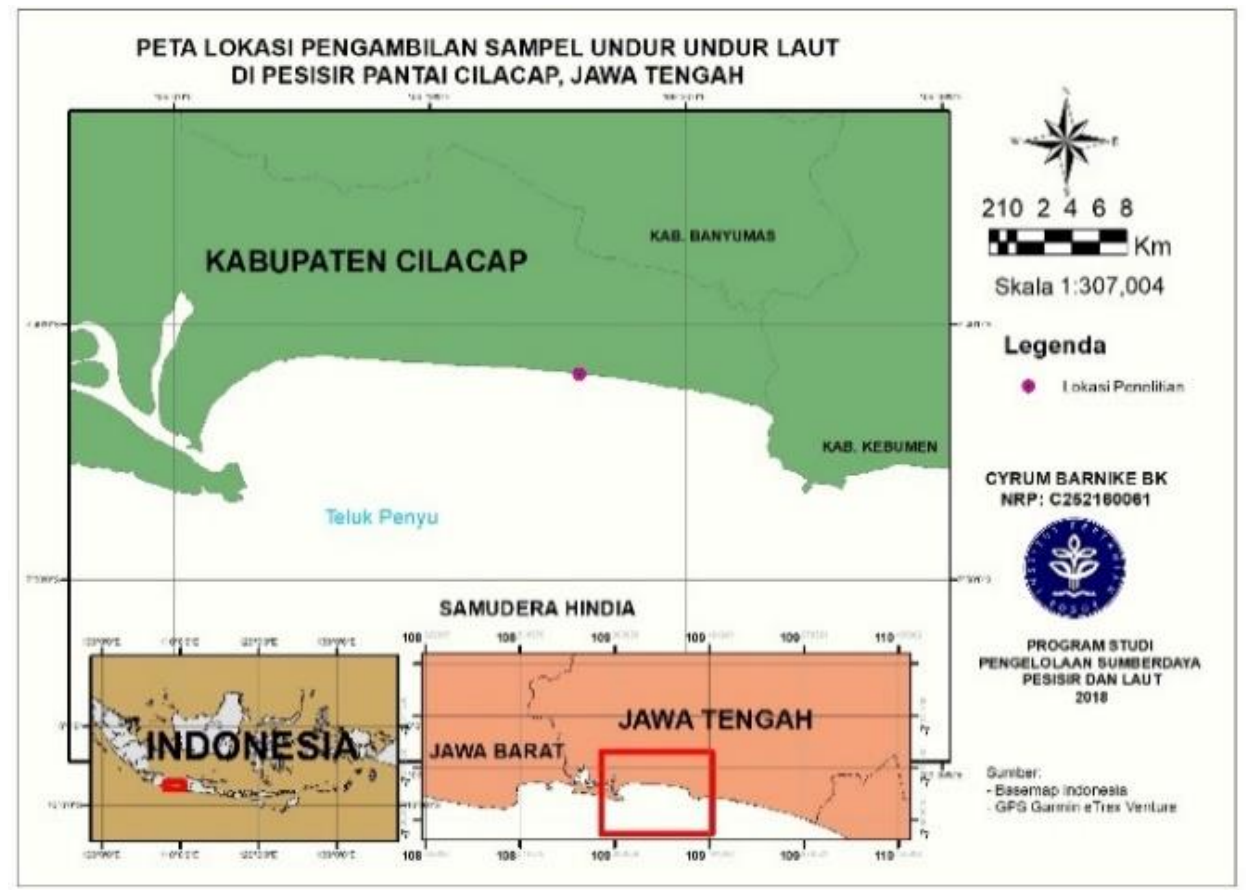

Gambar 1. Peta lokasi penelitian

\section{Karakterisasi Risiko}

Karakteristik risiko adalah perkiraan suatu risiko yang merugikan yang dapat terjadi pada manusia yang diakibatkan dari pajanan. Perkiraan tersebut dapat dilakukan melalui estimasi risiko, yaitu kuantifikasi probabilitas terjadinya risiko berdasarkan identifikasi bahaya, analisis efek, dan analisis pajanan. Tingkat risiko atau disebut RQ (Risk Quotients) adalah rasio intake dengan dosis referensi. Nilai RQ menunjukkan tingkat risiko untuk efek-efek nonkarsinogenik. Apabila RQ $<1$ menunjukkan indikasi tidak adanya 
kemungkinan terjadinya risiko efek yang merugikan. Sedangkan RQ > 1 menunjukkan indikasi adanya kemungkinan terjadinya risiko efek yang merugikan. Karakteristik risiko kesehatan untuk efek karsinogenik dinyatakan dengan ECR (Excess Cancer Risk). ECR dihitung dengan mengalikan CFS dengan intake karsinogenik risk agent (Ik). Baik CFS maupun Ik harus spesifik untuk bentuk spesifik kimia risk agent dan jalur pajanannya. Secara teoritis karsinogenisitas tidak mempunyai ambang atau non threshold maka risiko dinyatakan tidak bisa diterima (unacceptable) bila $10^{-6}<$ ECR $<10^{-4}$. Kisaran angka $10^{-6}$ sampai dengan $10^{-4}$ diambil dari nilai default karsinogenik (US EPA, 2001).

Persamaan yang digunakan untuk menghitung RQ adalah:

$\mathrm{RQ}=\frac{\mathrm{Ink}}{\mathrm{RfD}}$

Keterangan:

Ink = asupan (intake) non karsinogenik $(\mathrm{mg} / \mathrm{kg} \mathrm{bb}$ /hari)

$\mathrm{RfD}=$ dosis acuan (reference dose $)(\mathrm{mg} / \mathrm{kg} \mathrm{bb} / \mathrm{hari})$

Risiko kesehatan dinyatakan ada dan perlu dikendalikan jika RQ>1. Nilai ECR diperoleh dengan mengalikan Cancer Slope Factor (CSF) dengan asupan karsinogenik risk agent (Ik):

$\mathrm{ECR}=\mathrm{CSF} \times \mathrm{Ik}$

Risiko kesehatan tidak dapat diterima bila $10^{-6}<$ $\mathrm{ECR}<10^{-4}$. Jumlah asupan (intake) dihitung menggunakan persamaan (ATSDR, 2005):

$I=\frac{\mathrm{C} \times \mathrm{R} \times \mathrm{fE} \times \mathrm{Dt}}{\mathrm{Wb} \times \mathrm{tavg}}$

Keterangan:

I $\quad=\operatorname{asupan}(\mathrm{mg} / \mathrm{kg} / \mathrm{hari})$

$\mathrm{C} \quad=$ konsentrasi risk agent $(\mathrm{mg} / \mathrm{l})$

$\mathrm{R} \quad=$ laju asupan atau konsumsi (g/hari)

$\mathrm{f}_{\mathrm{E}} \quad=$ frekuensi pemaparan (hari/tahun)

Dt $=$ durasi pemaparan (30 tahun untuk nilai default residensial)

$\mathrm{Wb}=$ berat badan $(\mathrm{kg})$

$\mathrm{t}_{\mathrm{avg}}=$ periode waktu rata-rata $(70$ tahun $\mathrm{x} 365$ hari/tahun untuk zat karsinogen (Ik) Dt atau 30 tahun x 365 hari/tahun untuk zat nonkarsinogen (Ink).

Paparan yang berkaitan dengan kontaminasi $\mathrm{Pb}$ dikuantifikasi dengan analisis risiko kesehatan terhadap penduduk yang melakukan aktivitas langsung di perairan tersebut (berenang dan mencari ikan). Model yang digunakan adalah model analisis risiko kesehatan SEDISOIL yang dikembangkan oleh National Institute of Public Health and Environmental Protection (Albering et al., 1999). Model tersebut mencakup lima jalur pemaparan, yaitu sedimen, air permukaan, material tersuspensi, kontak kulit dengan air permukaan, dan kontak kulit dengan sedimen. Persamaan yang digunakan dalam model untuk menghitung total pemaparan adalah:

1) Asupan (intake) bersumber dari sedimen $(\mathrm{mg} / \mathrm{kg}$ $\mathrm{bb} /$ hari)

$$
\mathrm{I}_{d s}=\frac{\mathrm{CS} \times \mathrm{IRs} \times \mathrm{EF} \times \mathrm{AF}}{\mathrm{Wb}}
$$

Keterangan:

$\mathrm{CS}=$ konsentrasi kontaminan dalam sedimen $(\mathrm{mg} / \mathrm{kg}$ dw)

IRs = laju asupan sedimen ( $\mathrm{kg} \mathrm{dw} /$ hari paparan $)$

$\mathrm{EF}=$ frekuensi paparan (hari/365 hari)

$\mathrm{AF}=$ faktor absorpsi (tanpa satuan), dan

$\mathrm{Wb}=$ berat badan $(\mathrm{kg})$

2) Asupan yang bersumber dari air permukaan ( $\mathrm{mg} / \mathrm{kg}$ $\mathrm{bb} / \mathrm{hari}$ )

$$
\mathrm{I}_{w s}=\frac{\mathrm{CW} \times \mathrm{IRw} \times \mathrm{EF} \times \mathrm{AF}}{\mathrm{Wb}}
$$

Keterangan:

$\mathrm{CW}=$ konsentrasi kontaminan dalam air permukaan (mg/l)

$\mathrm{IRw}=$ laju asupan air permukaan (liter/hari paparan)

3) Asupan yang bersumber dari material tersuspensi ( $\mathrm{mg} / \mathrm{kg} \mathrm{bb} /$ hari):

$$
\mathrm{I}_{\mathrm{SM}}=\frac{\mathrm{CM} \times \mathrm{CMW} \times \mathrm{IRW} \times \mathrm{EF} \times \mathrm{AF}}{\mathrm{Wb}}
$$

Keterangan:

$\mathrm{CM}=$ konsentrasi kontaminan dalam material tersuspensi ( $\mathrm{mg} / \mathrm{kg} \mathrm{dw})$

$\mathrm{CMW}=$ kandungan material tersuspensi di air permukaan ( $\mathrm{kg} / \mathrm{liter})$

4) Asupan lewat kontak dermal dengan sedimen (mg/kg bb/hari)

$$
\mathrm{IKds}=\frac{\text { Cs } \times \text { SAs } \times \text { AD } \times \text { ASs } \times \text { Mf } \times \text { EDs } \times \mathrm{EF} \times \mathrm{AF}}{\mathrm{Wb}}
$$


Keterangan:

SAs = luas permukaan kulit untuk paparan sedimen $\left(\mathrm{m}^{2}\right)$

$\mathrm{AD}=$ laju kontak kulit dengan sedimen $\left(\mathrm{mg} / \mathrm{cm}^{2}\right)$

Ass = laju absorpsi dermal (liter/jam)

Mf = faktor matriks (tanpa satuan)

EDs = durasi pemaparan terhadap sedimen (jam/hari)

5) Asupan lewat kontak dermal dengan air permukaan ( $\mathrm{mg} / \mathrm{kg} \mathrm{bb} /$ hari)

$$
\mathrm{I}_{\mathrm{Kdw}}=\frac{\mathrm{Cw} \times \mathrm{SAw} \times \mathrm{ASw} \times \mathrm{EF} \times \mathrm{EDw} \times \mathrm{AF}}{\mathrm{Wb}}
$$

Keterangan:

$\mathrm{SAw}=$ luas permukaan kulit untuk pemaparan pada air permukaan $\left(\mathrm{m}^{2}\right)$

$\mathrm{ASw}=$ laju absorpsi dermal $\left[\left(\mathrm{mg} / \mathrm{m}^{2}\right) /(\mathrm{mg} / \mathrm{l}) / \mathrm{jam}\right]$

$\mathrm{EDw}=$ durasi pemaparan $(\mathrm{jam} / \mathrm{hari})$

Nilai default faktor-faktor pemaparan yang digunakan dalam pemodelan pemaparan untuk menghitung asupan berbagai jalur pemaparan mengacu pada nilai yang diberikan oleh (Albering et al., 1999) pada penentuan total tingkat pemaparan atau asupan logam berat melalui kelima jalur pemaparan, selanjutnya dibandingkan dengan asupan harian yang dapat ditoleransi (RfD). Tingkat bahaya (RQ) ditentukan dengan membandingkan jumlah paparan harian ratarata dengan $\mathrm{Rfd}$. Nilai rata-rata paparan harian $(\mathrm{mg} / \mathrm{kg}$ $\mathrm{bb} /$ hari) ditentukan menggunakan persamaan (Albering et al., 1999):

Jumlah Paparan harian rata-rata $=$

$\underline{6 \mathrm{x} \text { paparan harian anak }}+\underline{64 \mathrm{x} \text { paparan harian dewasa }}$

$\mathrm{RQ}=\frac{\sum \text { paparan harian rata-rata }}{\mathrm{RfD}}$

Jika nilai $R Q<1$, berarti tidak ada risiko bahaya yang terjadi.

\section{Manajemen Risiko}

Manajemen risiko akan dilakukan apabila tingkat risiko $(R Q)>1$. Caranya adalah dengan mengurangi laju asupan dan frekuensi pajanan secara matematik sehingga menjadi:

$$
\begin{aligned}
& R=\frac{R f D \times W b \times \text { tavg }}{C \times f E \times D t} \\
& F e=\frac{R f D \times W b \times \text { tavg }}{C \times R \times D t}
\end{aligned}
$$

\section{Hasil dan Pembahasan}

\section{Hasil}

\section{Konsentrasi Timbal (Pb) Di Air, Sedimen dan Undur-Undur Laut (Crustacea: Hippidae)}

Hasil konsentrasi pengukuran kandungan logam $\mathrm{Pb}$ pada sedimen, air, dan undur-undur laut (Hippidae) selama penelitian di sajiakan pada Tabel 1. Hasil penelitian didapatkan bahwa konsentrasi $\mathrm{Pb}$ air selama penelitian $0.007 \mathrm{mg} / \mathrm{l}$ konsentrasi logam $\mathrm{Pb}$ di sedimen berkisar antara 39.89-40.83 mg/kg $( \pm 40.83$ $\mathrm{mg} / \mathrm{kg}$ ), dan di biota undur-undur laut berkisar antara $0.97-0.98 \mathrm{mg} / \mathrm{kg}( \pm 0,97 \mathrm{mg} / \mathrm{kg})$.

Tabel 1. Hasil konsentrasi $\mathrm{Pb}$ pada air, sedimen dan undur-undur laut (Crustacea: Hippidae) selama penelitian

\begin{tabular}{cccccc}
\hline & Kandungan $\mathrm{Pb}$ & & $\begin{array}{c}\text { Rata- } \\
\text { rata }\end{array}$ & $\begin{array}{c}\text { Baku } \\
\text { mutu }\end{array}$ \\
\hline Air mg/l & 0.007 & 0.007 & 0.007 & 0,007 & $0,008^{1}$ \\
\hline $\begin{array}{c}\text { Sedimen } \\
\mathrm{mg} / \mathrm{kg}\end{array}$ & 40.43 & 39.89 & 40.83 & 40,38 & $30,2^{2}$ \\
\hline $\begin{array}{c}\text { biota } \\
\mathrm{mg} / \mathrm{kg}\end{array}$ & 0.98 & 0.96 & 0.97 & 2,26 & $0,20^{3}$ \\
\hline
\end{tabular}

${ }^{1}$ Baku mutu Kepmen - LK No. 51 Tahun 2004

${ }^{2}$ Canadian Sediment Quality for the Protection of Aquatic Life

${ }^{3}$ Badan Pengawas Obat dan Makan (BPOM) No. 23

Tahun 2017

\section{Risiko Kesehatan Pencemaran Logam Berat Timbal (Pb) di Perairan Pantai Widara Payung.}

Undur-undur laut merupakan bahan pangan yang digemari masyarakat pesisir, selain karena harganya yang murah, daging undur-undur laut memiliki rasa yang enak dan mengandung protein. Berdasarkan hasil wawancara, masyarakat memakan undur-undur laut berkisar antara 10 ekor untuk anakanak dan 20 ekor untuk dewasa setiap hari. Hal ini dikarenakan penangkapan undur-undur laut dilakukan setiap pagi, siang, dan sore sehingga undur-undur laut relarif tersedia. Adanya mesin pendingin dari beberapa pengepul mendukung persediaan bahan baku. Undurundur laut dikonsumsi masyarakat dalam bentuk yutuk crispy, yutuk rica-rica atau lauk yutuk dan rempeyek yutuk. Jumlah individu dalam $1 \mathrm{~kg}$ sekitar 90-141 ekor. Frekuensi pajanan $(\mathrm{Fe})$ adalah satu kali sehari dalam 365 hari/tahun. Durasi paparan adalah lamanya waktu responden mengkonsumsi undur-undur laut yang 
mengandung $\mathrm{Pb}$ dalam satuan tahun. Masyarakat umumnya telah tinggal disana dan mengkonsumsi undur-undur laut sejak lahir hingga dewasa sekitar 070 tahunan. Nilai Laju asupan, frekuensi paparan, serta konsentrai logam $\mathrm{Pb}$ pada dimasukan undur-undur laut dalam model simulasi. Nilai intake, $\mathrm{RQ}$, dan ECR hasil perhitungan pada masyarakat pesisir yang mengkonsumsi undur-undur laut disajikan pada Tabel 2.

Tabel 2. Nilai RQ dari total tingkat pemapaparan logam berat Pb pada Masyarakat Perairaan Widara Payung

\begin{tabular}{|c|c|c|c|c|c|c|c|}
\hline \multirow{2}{*}{ No } & \multirow{2}{*}{$\begin{array}{c}\text { Logam Berat dan } \\
\text { Jalur Paparanya }\end{array}$} & \multicolumn{2}{|c|}{ ulangan I } & \multicolumn{2}{|c|}{ ulangan II } & \multicolumn{2}{|c|}{ ulangan III } \\
\hline & & Anak-anak & Dewasa & Anak-anak & Dewasa & Anak-anak & Dewasa \\
\hline 1 & $\begin{array}{l}\text { Asupan bersumber } \\
\text { dari sedimen }\end{array}$ & 4,04E+00 & $6,06 \mathrm{E}-03$ & 2,79E-02 & $5,98 \mathrm{E}-03$ & $4,08 \mathrm{E}+00$ & $6,12 \mathrm{E}-03$ \\
\hline 2 & $\begin{array}{l}\text { Asupan yang } \\
\text { bersumber dari air } \\
\text { permukaan }\end{array}$ & 7,00E-04 & $1,50 \mathrm{E}-04$ & $7,00 \mathrm{E}-04$ & $1,05 \mathrm{E}-06$ & $7,00 \mathrm{E}-04$ & $1,50 \mathrm{E}-04$ \\
\hline 3 & $\begin{array}{l}\text { Asupan yang } \\
\text { bersumber dari } \\
\text { material tersuspensi }\end{array}$ & $3,60 \mathrm{E}-10$ & $1,05 \mathrm{E}-06$ & $5,46 \mathrm{E}-13$ & $1,67 \mathrm{E}-11$ & $3,60 \mathrm{E}-10$ & $1,05 \mathrm{E}-06$ \\
\hline 4 & $\begin{array}{l}\text { Asupan lewat } \\
\text { kontak dermal } \\
\text { dengan sedimen } \\
\end{array}$ & 0,1051 & 0,01364 & 0,0628 & 2,6927 & 0,0106 & 0,0138 \\
\hline 5 & $\begin{array}{l}\text { Asupan lewat } \\
\text { kontak dermal } \\
\text { dengan dermal } \\
\text { permukaan } \\
\end{array}$ & 0,7681 & 0,1559 & 0,7180 & 0,00003 & 0,77577 & 0,1575 \\
\hline & total & $4,81 \mathrm{E}+00$ & $1,76 \mathrm{E}-01$ & $8,09 \mathrm{E}-01$ & $2,70 \mathrm{E}+00$ & $4,87 \mathrm{E}+00$ & $1,78 \mathrm{E}-01$ \\
\hline & RQ & \multicolumn{2}{|c|}{505} & \multicolumn{2}{|c|}{1867.5} & \multicolumn{2}{|c|}{510} \\
\hline
\end{tabular}

\section{Manajemen Risiko Kesehatan}

Beberapa pilihan manajemen risiko dirumuskan tanpa mengurangi (menurunkan) konsentrasi logam berat dalam undur-undur laut yang merupakan makanan konsumsi masyarakat perairaan Pantai Widara Payung. Manajemen hanya dilakukan dengan mengubah laju konsumsi (R) undur-undur laut pada konsentrasi logam berat kelompok berisiko dengan menyusun ulang persamaan (1) menjadi persamaan (6). Manajemen juga dapat dilakukan dengan mengubah frekuensi paparan. Variabelvariabel lainnya dibiarkan tetap dengan 70 tahun durasi pajanan sepanjang hayat. Hasil simulasi ini ditampilkan pada Tabel 3.

Tabel 3. Laju asupan aman konsumsi undur-undur laut asal Pantai Widara Payung - Cilacap

\begin{tabular}{cccc}
\hline \multicolumn{2}{c}{ Laju Konsumsi $(\mathrm{g} / \mathrm{hr})$} & \multicolumn{2}{c}{ Frekunsi Paparan } \\
\hline Anak & Dewasa & Anak & Dewasa \\
\hline 1,75 & 2,63 & 0,029 & 0,043 \\
\hline
\end{tabular}

Pembahasan

\section{Konsentrasi Timbal $(\mathbf{P b})$ di air}

Konsentrasi $\mathrm{Pb}$ di dalam air selama penelitian berkisar antara $0.007 \mathrm{mg} / \mathrm{l}$. Mengacu pada baku mutu konsentrasi Pb berdasarkan Kepmen-LH No. 51 Tahun 2004 tentang baku mutu air laut untuk biota laut yaitu sebesar $0.008 \mathrm{mg} / \mathrm{l}$, maka kisaran konsentrasi $\mathrm{Pb}$ di Perairaan Pantai Widara Payung masih sesuai dengan bahan mutu yang telah ditetapkan. Berdasarkan hasil penelitian tingginya kandungan logam berat di perairan diduga disebabkan karna pengambilan sampel terjadi pada musim kemarau dalam keadaan surut sehingga kandungan logam berat tidak mengalami pengenceran.

\section{Konsentrasi Pb di Sedimen}

Konsentrasi logam berat dalam sedimen merupakan indikator yang baik pada suatu lingkungan yang tercemar logam berat. Kandungan logam berat dalam sedimen dapat digunakan untuk mengetahui tingkat risiko akibat paparan logam berat yang bersumber dari sedimen. Rata-rata kandungan logam 
$\mathrm{Pb}$ di sedimen rata-rata 40,38 mg/kg. Berdasarkan baku mutu Canadian Sediment Quality Guidelines for the Protection of Aquatic Life logam berat di perairaan pantai Widara Payung telah melewati baku mutu yang ditetapkan oleh (CCME, 2001) yaitu rata-rata 30,2 $\mathrm{mg} / \mathrm{kg}$ hasil ini telah melewati baku. Konsentrasi logam berat di sedimen berkorelasi positif dengan kandungan karbon organik dan tekstur sedimen. Umumnya logam berat teradsorbsi baik pada sedimen bertekstur liat, lumpur dan halus (Raj et al., 2013). Berdasarkan pemantauan selama penelitian tekstur sedimen selama penelitian berkisar antara lumpur yang halus hingga sangat halus. Logam berat yang masuk ke perairan akan segera berasosiasi dengan partikel sedimen dan terakumulasi di dasar perairan. Akumulasi logam berat dari air permukaan ke dasar perairan dipengaruhi oleh beberapa faktor lingkungan seperti $\mathrm{pH}$, kekuatan ion, masukan limbah antropogenik, komposisi nutrisi, jenis kandungan organik dan ukuran partikel (Aprile and Bouvy, 2008).

\section{Konsentrasi $\mathrm{Pb}$ di undur-undur laut}

Logam $\mathrm{Pb}$ banyak digunakan dalam industri baterai, industri percetakan (tinta), kabel, penyepuhan, pestisida, zat antiletup pada bensin, zat penyusun patri, dan sebagai formulasi penyambung pipa. Pencemaran timbal berasal dari sumber alami maupun limbah hasil aktivitas manusia dengan jumlah yang terus meningkat, baik di lingkungan air, udara, maupun tanah. Rata-rata konsentrasi logam $\mathrm{Pb}$ pada undur-undur laut yang diperoleh selama penelitian antara $0.96-0.96 \mathrm{mg} / \mathrm{kg}( \pm$ $0,97 \mathrm{mg} / \mathrm{kg}$ ). Berdasarkan rata-rata maka konsentrasi kandungan $\mathrm{Pb}$ pada undur-undur laut telah melebihi kandungan baku mutu berdasarkan Badan Pengawasan Obat dan Makanan (BPOM) No 23 Tahun 2017. Batas cemaran logam berat dalam pangan olahan untuk kandungan logam timbal $(\mathrm{Pb})$ untuk krustasea dengan batas maksimum $0,20 \mathrm{mg} / \mathrm{kg}$ sementara kandungan timbal $(\mathrm{Pb})$ undur-undur laut yang berdasarkan penelitian yakni sebesar berkisar $0,96-0,98 \mathrm{mg} / \mathrm{kg}( \pm$ $0,97 \mathrm{mg} / \mathrm{kg}$ ). Berdasarkan hasil penelitian tersebut undur-undur laut masih dapat dikonsumsi dengan ratarata konsumsi untuk anak-anak dengan laju konsumsi $1,75 \mathrm{gr} / \mathrm{hari}$ selama 60 hari selama satu tahun. Sementara itu, untuk dewasa 2,63 gr/hari dengan laju konsumsi 60 hari per tahun. Resiko kesehatan anak meningkat jika konsumsi lebih dari 60 hari per tahun maka nilai resiko kesehatan $(\mathrm{RQ})>1$ untuk widara payung.

\section{Risiko Kesehatan Pencemaran Logam Berat Pb di Perairaan Pantai Widara Payung}

\section{a. Tingkat Risiko Akibat Aktivitas Langsung}

Kegiatan industri dan masayarakat diduga membawa dampak bagi lingkungan perairan di Pantai Widara Payung. Kuantifikasi tingkat risiko yang berasal dari konsumsi undur-undur laut dengan menggunakan metode analisis risiko kesehatan (US EPA, 2001). Nilai risiko bisa diterima dan tidak berbahaya jika nilainya kurang dari satu $(\mathrm{RQ}<1)$. Sebaliknya, jika nilai RQ lebih dari 1, maka masyarakat memiliki risiko kesehatan akibat paparan logam berat. Rekapitulasi nilai tingkat risiko setiap asupan dapat dilihat pada Tabel 4. Kuantifikasi tingkat risiko (nilai RQ) di Perairaan Pantai Widara Payung yang berasal dari paparan air dan sedimen didapat dengan memasukkan nilai parameter dengan model yang ada sehingga diperoleh nilai intake (I) dan RQ. Tingkat resiko dipisahkan berdasarkan populasi masyarakat yang tergolong dewasa dan anak. Prakiraan tingkat risiko diestimasi dengan waktu selama 5 tahun pemaparan. Nilai I dan RQ logam berat untuk masingmasing stasiun pengamatan disajikan pada Tabel 4 .

Tabel 4. Nilai Intake, ECR, RQ masyarakat Perairan Widara Payung

\begin{tabular}{lcc}
\hline \multirow{2}{*}{ Nilai } & \multicolumn{2}{c}{ Widara Payung } \\
\cline { 2 - 3 } & Anak-anak & Dewasa \\
\hline Intake & 63,92 & 6,84 \\
\hline Karsinogen & 0,013 & 0,006 \\
\hline ECR & 63,92 & 6,84 \\
\hline Nontake & 15980 & 1710 \\
\hline RQ $>1$ &
\end{tabular}

Berdasarkan Nilai RQ dari total tingkat pemaparan logam berat $\mathrm{Pb}$ pada masyaratkat Perairaan Widara Payung (Tabel 4), nilai RQ untuk Pb Perairaan Pantai Widara Payung berkisar antara 505-1807.5. Nilai RQ untuk logam $\mathrm{Pb}$ di masing-masing muara secara keseluruhan prakiraan dampak setelah lima tahun menunjukkan nilai diatas 1 (RQ $>1)$. Hal tersebut menunjukkan bahwa masyarakat di Perairan Pantai Widara Payung belum aman terhadap ancaman risiko kesehatan akibat paparan logam $\mathrm{Pb}$ selama melakukan aktivitas langsung di Perairaan Pantai Widara Payung. Dengan mengacu nilai RQ yang lebih dari 1 memperlihatkan bahwa Perairaan Pantai Widara Payung memerlukan pengendalian pencemaran dan pencegahan pemaparan langsung. Penelitian mengenai analisis risiko kesehatan akibat paparan logam berat 
yang berasal dari air dan sedimen juga telah dilakukan di Pesisir Kabupaten Tangerang (Simbolon, 2014). Penelitian tersebut menujukkan bahwa konsentrasi logam $\mathrm{Pb}, \mathrm{Cd}$, dan $\mathrm{Zn}$ telah memiliki nilai RQ di atas 1, sehingga masyarakat yang beraktivitas langsung diperairan tersebut memiliki risiko kesehatan terhadap logam berat khususnya logam $\mathrm{Pb}, \mathrm{Cd}$, dan $\mathrm{Zn}$.

\section{b. Tingkat Risiko Akibat Konsumsi Undur-Undur}

\section{Laut}

Logam berat timbal $(\mathrm{Pb})$ merupakan logam yang bersifat karsinogenik, sehingga tingkat risiko karsinogen untuk timbal didefinisikan sebagai banyaknya intake harian kronik dikalikan dengan faktor slope karsinogenik yang didapatkan dari perkiraan daya racun. Tingkat risiko melalui konsumsi undur-undur laut dapat diketahui dengan menghitung nilai asupan (intake) (US EPA, 2001) dengan berat badan anak yaitu $15 \mathrm{~kg}$ dan dewasa sebesar $70 \mathrm{~kg}$. Berdasarkan hasil simulasi pada Tabel 4 nilai RQ di atas 1 (RQ>1). Nilai RQ pada populasi anak-anak dan dewasa masing-masing sebesar 15980 dan 1710. Berdasarkan estimasi risiko tersebut, logam berat timbal $(\mathrm{Pb})$ yang terdapat dalam undur-undur laut beresiko untuk populasi anak-anak dengan berat badan $15 \mathrm{~kg}$ dan dewasa dengan berat badan $70 \mathrm{~kg}$ apabila undur-undur laut dimakan sebanyak 10-20 gram selama 365 (satu tahun). Estimasi tersebut dihitung untuk durasi default sepanjang hayat (lifetime) 30 tahun sehingga efek-efek toksisitas logam berat mungkin baru dirasakan dalam masa 30 tahun ke depan juga.

Nilai ECR > 1 menunjukkan bahwa ada kasus tambahan kanker kurang dari setiap 10.000 . Berdasarkan perhitungan dari model yang digunakan nilai ECR untuk logam timbal $(\mathrm{Pb})$ di masing-masing lokasi pengambilan sampel telah sampai pada $10^{-6} \mathrm{Hal}$ tersebut menunjukkan bahwa undur-undur laut tidak aman dikonsumsi sebanyak 10-20 gr/hari selama 365 hari/tahun dalam jangka waktu 30 tahun oleh orang dengan berat badan $15 \mathrm{~kg}$ pada anak, dan $70 \mathrm{~kg}$ pada dewasa. Konsumsi undur-undur laut akan meningkatkan efek toksisitas baru akan terasa setelah 30 atau 70 tahun kedepan dengan tingkat konsumsi 1020 gr/ hari selama 365 hari per tahun. Secara keseluruhan perhitungan tersebut dapat disimpulkan bahwa undur-undur laut di perairaan Pantai Widara Payung tidak layak untuk dikonsumsi. Sebagai pembanding, (El Nemr et al., 2012) melakukan penelitan pada mayarakat yang mengkonsumsi moluska di Muara Mediterania Mesir menghasilkan nilai $\mathrm{RQ}$ pada moluska untuk logam $\mathrm{Pb}, \mathrm{Cd}$, dan $\mathrm{Zn}$ masih di bawah $1(\mathrm{RQ}<1)$. Hal tersebut menunjukkan bahwa masyarakat di Muara Mediterania Mesir masih belum berisiko terhadap paparan logam berat akibat konsumsi moluska. Demikian halnya dengan penelitian Bogdanovic et al. (2014) yang melakukan penelitian analisis risiko kesehatan akibat konsumsi kerang yang berasal dari Perairan Kroasia. Nilai RQ yang dihasilkan masih dibawah 1 sehingga masyarakat yang mengkonsumsi kerang masih aman terhadap risiko kesehatan logam berat.

\section{Manajemen Risiko Kesehatan}

Tingkat risiko kesehatan masyarakat di Perairan Pantai Widara Payung yang dikuantifikasi baik yang berasal dari air, sedimen dan mengkonsumsi undur-undur laut menunjukkan nilai diatas 1 (RQ>1). Sehingga masyarakat di Perairaan Pantai Widara Payung memiliki risiko kesehatan akibat paparan logam berat. Risiko kesehatan dapat dikurangi bahkan dicegah dengan adanya manajemen risiko kesehatan. Prinsip pengelolaan risiko dalam analisis risiko kesehatan lingkungan (ARKL) dilakukan apabila tingkat risiko $(\mathrm{RQ})>1$.

Berdasarkan Tabel 6 maka laju konsumsi aman undur-undur laut bagi masyarakat di Perairan Perairaan Pantai Widara Payung agar tidak terkena risiko kesehatan akibat paparan logam $\mathrm{Pb}$ yaitu minimal 1, 75 gr/hari untuk anak-anak dengan berat badan $15 \mathrm{~kg}$ dan 2,63 gr/hari untuk orang dewasa dengan berat badan $70 \mathrm{~kg}$ dengan jangka waktu pertahun sebanyak 60 hari. Masyarakat di perairan ini dianjurkan untuk mengkonsumsi undur-undur laut dengan laju frekuensi pemamaparan minimal 0,029 per hari selama 60 hari setiap tiap tahunnya untuk populasi anak-anak dan 0,043 perhari selama 60 per tahunnya untuk populasi dewasa. Selain mengubah laju asupan dan frekuensi paparan dari konsumsi undur-undur laut, manajemen risiko juga dilakukan dari sumber pencemar logam berat. Manajemen dapat berupa pencegahan dan pengendalian pada industri yang menghasilkan limbah logam berat seperti industri tekstil, logam, dan batu baterai, perkapalan yang terdapat di sepanjang Perairan Pantai Selatan Jawa, Khususnya Cilacap. Pencegahan dapat dilakukan dengan pengawasan terhadap kebijakan mengenai baku mutu limbah bagi setiap perusahaan. Pengaawasan terhadap aktivitas pembuangan limbah disekitar perairaan Cilacap dengna dibangungan instalasi pengolohan limbah (IPAL). Selain itu, pengendalian pencemaran seperti dilakukannya penanaman kembali hutan mangrove. Penegakan hukum seperti pemberian hukuman atau sanksi bagi pengusaha yang melanggar aturan pengolahan limbah 
mutlak dilakukan agar kasus pencemaran di wilayah Perairaan Pantai Selatan Jawa, Khusunya Cilacap.

\section{Kesimpulan}

Berdasarkan hasil penelitian ini dengan melihat nilai rata-rata yaitu kandungan logam $\mathrm{Pb}$ di undur-undur laut sudah melebihi baku mutu yang ditetapkan namun resiko kesehatan akan meningkat dengan seiring laju konsumsi yang semakin banyak pertahunnya. Tingkat resiko kesehatan logam $\mathrm{Pb}$ yang dikuantifikasi baik yang berasal dari air, sedimen, konsumsi undur-undur laut menunjukkan nilai diatas $1(\mathrm{RQ}>1)$ dan ECR $>10^{-}$ ${ }^{6}$. Dengan demikian masyarakat Perairan Pantai Widara Payung memiliki resiko kesehatan akibat paparan logam timbal $(\mathrm{Pb})$. Risiko kesehatan dapat dikurangi bahkan dicegah dengan adanya manajemen risiko kesehatan yaitu dengan cara mengurangi laju asupan makanan undur-undur laut, frekuensi paparan dapat dikurangi dan pengendalian dapat dilakukan dari sumber pencemar limbah.

\section{Ucapan Terima Kasih}

Penulis mengucapkan terima kasih kepada Lemabaga Pengelola Dana Pendidikan yang telah membiayai penelitian ini. Ucapan terimakasih juga disampaikan kepada keluarga dan sahabat dekat yang telah memberi dorongan moral dan moril. Kepada seluruh warga Widara Payung yang telah membantu dalam pengumpulan sampel penelitian ini.

\section{Daftar Pustaka}

APHA. (2005). Standard Methods For The Examination Of Water and Waste Water. 22th eds. Washington DC (US). American Water Works Assosiation and Water Pollution Control Federation.

Albering, J.H., Jean, P.R., Edwin, J.C.M., Jurian, A.H. \& Jos C.S.K. (1999). Human Health Risk Assessment in Relation to Environmental Pollution of Two Artificial Freshwater Lakes in The Netherlands. Environmental Health Perspectives, 107 (1) : 27-35. DOI: https://doi.org/10.1289/ehp.9910727

Aprile, F.M. \& Bouvy, M. (2008). Distribution and Enrichment of Heavy Metals in Sediments at The Tapacurá River Basin, Northeastern Brazil. Braz. Journal Aquat. Sci, 12 (1) : 1-8. DOI :https://doi.org/10.14210/bjast.v12n1p1-8
ATSDR. (2005). Agency For Toxic Substances And Disease Registry. Public Health Assessment Guidance Manual (Update). Atlanta. Department Of Health And Human.

Besser, J.M., William, G.B., Thomas, W.M. \& Christopher, J.S. (2007). Biomonitoring of Lead, Zinc, and Cadmium in Streams Draining Lead-Mining and Non-Mining Areas, Southeast Missouri, USA. Journal Environ Monit Assess. 129 : 227-241. DOI: https://doi.org/10.1007/s10661-006-9356-9

Bhagawati, D., Anggoro, S., Zainuri, M. \& Sya'rani, L. (2016). Ethnotaxonomical Study of Mole Crab (Crustacea: Hippoidea) on Coastal Community Cilacap. Biosaintifika: Journal of Biology \& Biology Education: 8 (2) : 222-231. DOI: https://doi.org/10.15294/biosaintifika.v8i2.649 $\underline{1}$

Bogdanovic, T., Ivana, U., Marija, S., Eddy, L., Vida, S., Sandra, P. \& Vedran, P. (2014). As, Cd, Hg and $\mathrm{Pb}$ in Four Edible Shellfish Species From Breeding and Harvesting Areas along The Eastern Adriatic. Coast, Croatia. Journal Food Chemistry, 146 : 197-203. DOI: https://doi.org/10.1016/j.foodchem.2013.09.04 $\underline{5}$

CCME. (2001). Canadian Sediment Quality Guidelines for the Protection of Aquatic Life. Canada. Canadian Environmental Quality Guidelines.

Dugan, J., Ichikawa, G., Stephenson, M., Crane, D.B, Mc Call, J. \& Regalado, K. (2005). Monitoring of coastal contaminants using sand crabs. Central Coast Regional Water Quality Control Board.37 pp.

El Nemr, A., Azza, K., Abeer, A.M. \& Amany, E.S. (2012). Risk Probability Due to Heavy Metals in Bivalvefrom Egyptian Mediterranean Coast. Egyptian Journal of Aquatic Research, (38) : 67-75.

DOI: https://doi.org/10.1016/j.ejar.2012.11.001

Hartono, E., Rejeki, E.S. \& Puspitasari, A.A. (2011). Pengaruh Asupan Makanan Undur-Undur Laut Terhadap Kandungan Omega 3 Pada Telur Itik. Jurnal Biomedika, 4 : 60-65. 
Huboyo, H.S. \& Syafrudin. (2007). Analisis Resiko Konsentrasi Debu (TSP) dan Timbal (Pb) di Pinggir Jalan Terhadap Kesehatan Manusia Studi Kasus Kota Yogyakarta. Teknik, 28 (2) : 142-149.

IPCS. (2004). Environmental Health Criteria XXX: Principles for Modelling Dose-Response for The Risk Assessment of Chemicals. Geneva.

Jaffrennou, C., Giamarchi, P., Cabon, JY., Stephan, L., Burel, DL., Bautin, F., Thomas, A., Dumont, J., \& Floch, L.S. (2007). Simulations Of Accidental Coal Immersion. Marine Pollution Bulletin, 54 : 1932 1939. DOI: https://doi.org/10.1016/j.marpolbul.2007.08.01 7.

KMNLH. (2004). Keputusan Menteri Negara dan Lingkungan Hidup No.51 tentang Baku Mutu Air Laut untuk Kehidupan Biota Laut.

Mashar, A. (2016). Biologi populasi undur-undur laut (Crustasea: Hippidae) di Pantai Selatan Jawa Tengah (Disertasi). Institut Pertanian Bogor. Jawa Barat.

Mashar, A., Wardianto, Y., Butet N.A. \& Farallah A. (2014). Diversitas dan Kelimpahan Kepiting Pasir Di Pantai Selatan Jawa Tengah. Jurnal Ilmu Kelautan : 19 (4): 226-232. DOI : http://doi.org.10.14710/ik.ijms.19.4.226-232

Mashar, A. \& Wardiatno, Y. (2013). Aspek Pertumbuhan Undur-Undur Laut, Emerita Emeritus dari Pantai Berpasir Kabupaten Kebumen. Jurnal Biologis Tropis, 13 (1) : 2938. DOI : http://dx.doi.org/10.29303/jbt. v13i1.70

Mashar A. \& Wardiatno, Y. (2016). Biomassa Sesaat Sumber Daya Perikanan Undur-Undur Laut (Crustasea: Decapoda: Hippidea) di Pantai Berpasir Cilacap dan Kebumen, Jawa Tengah. Marine Fisheries. (7) : 211-218. DOI: http://dx.doi.org/10.29244/jmf.7.2.211218 .

Muzammil, W., Wardiatno, Y. \& Butet, N.A. (2015). Carapace Length-Width, Relative Growth, Condition Factor, And Relative Condition Factor Of The Mole Crab (Hippa Adactyla) In Cilacap And Kebumen Sandy Beach. Ilmu Pertanian Indonesia, 20 (1) : 78-84.
Raj, S., Pravas, K.J. \& Chitta, R.P. (2013). Textural and Heavy Metal Distribution in Sediments of Mahanadi estuary, East Coast of India. Indian Journal of Geo-Marine Sciences. 42 (3) : 370374.

Siegel, P.R. \& Wenner, A.M. (1984). Field And Laboratory Studies Of Sand Crab Growth. In Wenner, A.M. (Ed.), Crustacean Growth, Crustacean Issues, Vol II. Rotterdam. Balkema Press.

Simbolon, A.R. (2014). Analisis kualitas lingkungan hidup simping (Placuna Placenta) di Pesisir Kabupaten Tangerang dan risiko kesehatan yang ditimbulkan (Tesis). Institut Pertanian Bogor. Jawa Barat.

Subramoniam, T. (2014). Mole Crab As The Indicator Species And A Model Organisme to Study Effect of Heated Effluent Discharge From Atomic Power Plant To The Intertidal Zone. Journal Indian Nuclear Society News, 11 (1\&2) : 17-21.

US EPA. (2000). National Water Quality Inventory 2000 Report. US Environmental Protection Agency. Washington DC (US).

US EPA. (2001). Toxics Release Invebtory (TRI) Public Data Release Executive Summary. Washington DC. (US) Enviromental Protection Agency.

Wenner, A.M. (1988). Crustaceans and other invertebrates as indicators of beach pollution. In Soule, D.F., \& Kleppel, G.S. (Eds.), Marine Organisms as Indicators (pp: 199-229). New York. Springer-Verlag. 